\title{
IMPACT OF BIOFERTILIZERS AS A PARTIAL AND SAFE SUBSTITUTE OF NITROGEN FERTILIZER ON SOME GROWTH, PHOTOSYNTHETIC PIGMENTS AND YIELD TRAITS IN COTTON PLANTS
}

(Received: 2.9.2012)

\author{
By \\ M. D. H. Dewdar and M. M. Rady* \\ Agronomy Department and* Botany Department, Faculty of Agriculture, Fayoum University,Egypt.
}

\begin{abstract}
Attention has been focused on the use of organic and bio-fertilizers due to the pollution factor and high costs of mineral fertilizers. Therefore, two field experiments were conducted at the Experimental Farm of the Faculty of Agriculture at Fayoum in two successive growing seasons 2010 and 2011 to study the effect of bio-fertilizers (Microbin and Cerealin) with different levels of nitrogen. The treated cotton plants with inorganic $\mathrm{N}$ combined with microbin or cerealin bio-fertilizers improved all the studied growth traits of cotton, i.e. plant height, the number of leaves per plant, the total leaf area per plant and dry weight of leaves per plant as compared to the control treatment. The best results were observed when cotton plants were treated with $100 \%$ inorganic $\mathrm{N}$ combined with microbin or cerealin for plant height trait in both seasons. Treatment of $80 \% \mathrm{~N}+$ microbin or cerealin ranked as the first favorable treatments for enhancing cotton yield and leaf pigments in both seasons. From the obtained results, it could be concluded that the application of $80 \% \mathrm{~N}+$ microbin or cerealin were favorable treatment for producing significantly higher yield with improved growth traits and seed cotton yield saving $20 \%$ of $\mathrm{N}$ fertilizer.
\end{abstract}

Key word: biofertilizer, cerealin, cotton, microbin, $N$ inorganic.

\section{INTRODUCTION}

Cotton is still playing an essential role in the national economy of Egypt. Bio-fertilizers became a positive substitute portion of chemical fertilizers, safe for human, animal and environment. They help in improving crop productivity and quality by increasing biological $\mathrm{N}$ fixation, availability and uptake of nutrients, and stimulating the natural hormones (Kannaiyan, 2002).

Singh and Bisoyi (1995) concluded that biofertilizers like Azotobacter, Azospirillum and Rizobium were important for different crops, and addition of bio-fertilizers had an effective role in $\mathrm{N}$ fixation and biomass accumulation beside their favorable effect on mineralization and balance of soil N. Further, Neeru et al. (2005 a and b) reported that high $\mathrm{N}$ fixing, phosphate solubilizing, phytohormones producing isolates of Azotobacte, Azospirillum, Acetobacter and Pseudomonas were used as inoculants with varying doses of nitrogen for cotton.

The biofertilizers under optimum conditions could enhance the crop yield by 10-20\% and saved chemical $\mathrm{N}$ fertilizer by $15-25 \%$
(Chowdhury and Mukherjee ,2008).

Saleh et al. (2004), El- Sayed and ElMenshawi (2005), Hamed (2006) and Toaima (2007) demonstrated that plant height, boll weight , number of bolls per plant and seed cotton yield per feddan were increased significantly by $\mathrm{N}$ application. Generally, $\mathrm{N}$ fertilizer is an important and limiting factor for growth and productivity of cotton. It has many functions in plant life, being part of proteins, an important constituent of protoplasm, responsible for the biosynthesis of enzymes, amino acids, plant pigments and encouragement of cell division.

Many authors studied the effect of biofertilizers on different crops, i.e. Ibrahim et al. (2004) and Zeidan et al. (2005) for wheat, Wu et al. (2005) for maize, Rokhzadi et al. (2008) for chickpea and Megawer \& Mahfouz (2010) for rape.

Few investigators studied the effect of application of bio-fertilizers to increase the productivity of cotton. (Hamissa et al., 2000; Sobh et al., 2000; Sundaravardarajan et al., 2006; AlMohamed et al., 2009).

The main objective of the study was to throw some light on the effect of present bio and $\mathrm{N}$ 
mineral fertilization on growth, leaf pigment assessments and yield traits of cotton plants.

\section{MATERIALS AND METHODS}

Two field trials were conducted during the two successive seasons of 2010 and 2011 at the Experimental Farm of the Faculty of Agriculture at Fayoum, to study the effect of bio and $\mathrm{N}$ fertilization on cotton plants, Giza 90. The soil properties were: coarse sand $5.57 \%$, fine sand $22.11 \%$, silt $19.23 \%$, clay $53.09 \%$, pH 7.21, organic matter $1.47 \%$, calcium carbonate $5.43, \mathrm{Ec}$ 1.6, available $\mathrm{N}, \mathrm{P}$ and $\mathrm{K}, 72.00,19.00$ and 696.00 ppm, respectively (Page et al., 1982 and Klute, 1986).

$\mathrm{N}$ fertilizer levels in the form of urea $(46 \% \mathrm{~N})$ were applied in two equal doses, the $1^{\text {st }}$ dose was after thinning and the $2^{\text {nd }}$ one was added at the following irrigation. Phosphorus fertilizer was added at a rate of $22.5 \mathrm{~kg} \mathrm{P}_{2} \mathrm{O}_{5} /$ fed. during land preparation. Potassium fertilizer was added at rate of $50 \mathrm{~kg}$ in forms of potassium sulphate $(48 \%$ $\mathrm{K}_{2} \mathrm{O}$ ) in one dose was added by at the time of applying the $1^{\text {st }}$ dose of $\mathrm{N}$.

Two $\mathrm{K}_{2} \mathrm{O}$ were used in the present study, i.e., microbin (Azotobacter chroococcum) and cerealin (Bacillus polymyxa). Arabic gum was melted in an amount of warm water and was added to each of the previous two bio-fertilizers. Cotton seeds were added to the mixture of bio-fertilizer and gum, mixed carefully and spread over plastic sheet far from the direct sun effect for a short time before sowing (Allen, 1971). Sowing irrigation was done immediately to provide a suitable moisture condition for inoculation, while the control treatment was without inoculation.

The experimental design was randomized complete block design with four replications and 9 treatments included:

(T1) $100 \% \mathrm{~N}$ of $(75 \mathrm{~kg} \mathrm{~N} / \mathrm{fed}$; control treatment).

(T2) $80 \% \mathrm{~N}$ of recommended dose.

(T3) $60 \% \mathrm{~N}$ of recommended dose.

(T4) $100 \% \mathrm{~N}$ of recommended dose+ Microbin.

(T5) $80 \% \mathrm{~N}$ of recommended dose + Microbin.

(T6) $60 \% \mathrm{~N}$ of recommended dose + Microbin.

(T7) $100 \% \mathrm{~N}$ of recommended dose + Cerealin.

(T8) $80 \% \mathrm{~N}$ of recommended dose + Cerealin.

(T9) $60 \% \mathrm{~N}$ of recommended dose + Cerealin.

The plot size was $10.5 \mathrm{~m}^{2}(3.0 \times 3.5 \mathrm{~m})$. The ordinary cultural practices for growing cotton were adopted as recommended at the location, except the experimental treatments. Sowing dates were March 15 and 17 for the first and second seasons, respectively. Five individual random guarded plants were tagged to collect the data but seed cotton yield was weight of the inner rows of each plot in terms of $\mathrm{Kg} /$ plot and converted to kentar / feddan.

The studied traits were; I-Growth traits [Plant height $(\mathrm{cm})$, number of leaves per plant, total leaf area per plant $\left(\mathrm{dm}^{-2}\right)$ and dry weight of leaves per plant (g)]. II- Photosynthetic pigments assessments [(chlorophyll A and B (mg/g, F.W.) were determined according to Arnon (1949), total carotenoid concentration (mg/g, F.W.) in fresh leaves were estimated by the method described by Welburm and Lichtenthaler (1984) and total sugars $(\mathrm{mg} / \mathrm{g}, \mathrm{D}$. W.) were determined according to A.O.A.C. (1995)]. III-Yield and its components; [ seed cotton yield (Kentar/fed.), number of bolls /plant, boll weight (g), lint percentage (\%), seed index (g) and lint index (g)]. The data were subjected to analysis of variance according to Gomez and Gomez (1984) using MSTAT statistical package. The means were compared using NEW LSD test at the $5 \%$ level.

\section{RESULTS AND DISCUSSION}

\subsection{Growth parameters}

Results presented in Table (1) indicated that growth traits i.e., plant height, number of leaf per plant, total leaves area per plant and dry weight of leaf per plant were significantly positively affected by the treatments of nitrogen fertilizer and/or with inoculation of biofertilizers microbin or cerealin in both seasons. The highest values of plant height were obtained with the biofertilizers cerealin or microbin combined with the chemical fertilizers 80 or $100 \% \mathrm{~N}$ treatments (T4, T5, T7 and $\mathrm{T} 8$ ) in both seasons. The data also indicated that the application of boifertilizers increased plant height significantly compared to that of nitrogen treatments $(60$ or $80 \% \mathrm{~N}$;(T2 and T3) which in turn scored a significant increments in this parameter as compared to the control (T1). The enhanced plant height obtained occurred by the fact that biofertilizers encouraged a fixing molecular nitrogen and its transfer to the plant as a direct effect on growth hormones auxins.

While, no significant differences were obtained between the two treatments of T6 and T9 for the same trait. The results cleared that the treatment of T8 which is a combination between $80 \% \mathrm{~N}$ and incoculation of cerealin, followed by $\mathrm{T} 5$ and they exerted the highest values for the number of leaves per plant; total leaf area per plant and dry weight of leaves per plant as compared to the control in both seasons. The obtained values were $47.00,46.00,66.73,65.00,28.33$ and 28.66 in the 
Table (1): Mean values of growth traits as affected by nitrogen fertilizer rates and biofertilizers in the two growing seasons.

\begin{tabular}{|c|c|c|c|c|c|c|c|c|}
\hline \multirow{2}{*}{ Treatments } & \multicolumn{2}{|c|}{$\begin{array}{c}\text { Plant height } \\
\text { at harvest }(\mathrm{cm})\end{array}$} & \multicolumn{2}{|c|}{$\begin{array}{l}\text { Number } \\
\text { of leaves }\end{array}$} & \multicolumn{2}{|c|}{$\begin{array}{c}\text { Total leaf } \\
\text { Area }\left(\mathbf{d m}^{-2}\right)\end{array}$} & \multicolumn{2}{|c|}{$\begin{array}{l}\text { Dry weight } \\
\text { of leaves (g) }\end{array}$} \\
\hline & $\begin{array}{c}\mathbf{1}^{s t} \\
\text { Season }\end{array}$ & $\begin{array}{c}2^{\text {nd }} \\
\text { Season }\end{array}$ & $\begin{array}{c}\mathbf{1}^{s t} \\
\text { Season }\end{array}$ & $\begin{array}{c}2^{\text {nd }} \\
\text { Season }\end{array}$ & $\begin{array}{c}\mathbf{1}^{s t} \\
\text { Season }\end{array}$ & $\begin{array}{c}2^{\text {nd }} \\
\text { Season }\end{array}$ & $\begin{array}{c}\mathbf{1}^{s t} \\
\text { Season }\end{array}$ & $\begin{array}{c}2^{\text {nd }} \\
\text { season }\end{array}$ \\
\hline T1: 100\% N (control) & 114.0 & 115.3 & 37.33 & 35.66 & 53.00 & 52.33 & 21.76 & 19.33 \\
\hline T2: $80 \% \mathrm{~N}$ & 115.3 & 116.0 & 36.33 & 32.66 & 49.26 & 44.33 & 21.00 & 17.00 \\
\hline T3: $60 \% \mathrm{~N}$ & 98.6 & 95.00 & 31.66 & 31.00 & 48.96 & 44.33 & 20.16 & 17.33 \\
\hline $\begin{array}{l}\text { T4: } 100 \% \mathrm{~N}+ \\
\text { Microbin }\end{array}$ & 127.0 & 128.0 & 42.00 & 37.33 & 62.33 & 58.33 & 25.93 & 23.00 \\
\hline $\begin{array}{l}\text { T5: } 80 \% \text { N + } \\
\text { Microbin }\end{array}$ & 125.0 & 126.3 & 44.33 & 45.00 & 63.00 & 62.33 & 27.63 & 27.00 \\
\hline $\begin{array}{l}\text { T6: } 60 \% \text { N + } \\
\text { Microbin }\end{array}$ & 99.33 & 96.67 & 33.33 & 40.66 & 49.66 & 47.00 & 20.90 & 17.66 \\
\hline $\begin{array}{l}\text { T7: } 100 \% \text { N + } \\
\text { Cerealin }\end{array}$ & 128.3 & 130.3 & 43.33 & 42.00 & 52.66 & 54.00 & 27.00 & 20.00 \\
\hline $\begin{array}{l}\text { T8: } 80 \% \text { N + } \\
\text { Cerealin }\end{array}$ & 127.7 & 128.3 & 47.00 & 46.00 & 66.73 & 65.00 & 28.33 & 28.66 \\
\hline $\begin{array}{l}\text { T9: } 60 \% \mathrm{~N}+ \\
\text { Cerealin }\end{array}$ & 97.67 & 98.66 & 34.66 & 34.33 & 50.66 & 46.33 & 22.63 & 19.00 \\
\hline NEW LSD at $5 \%$ & 4.32 & 5.27 & 1.33 & 2.77 & 5.06 & 6.61 & 1.115 & 1.117 \\
\hline
\end{tabular}

first and second seasons respectively for $\mathrm{T} 8$ treatment. Further, the beneficial effect of the treatments $\mathrm{T} 4, \mathrm{~T} 6, \mathrm{~T} 7$ and $\mathrm{T} 9$ resulted in improvements of the previously three growth traits. These results are in agreement with those obtained by Kannaiyan (2002) and Hamed (2006).

$\mathrm{N}$ fertilizer rate gave a significant effect on the same traits in both seasons. Increasing $\mathrm{N}$ rate up to the recommended dose increased significantly all growth traits. This may be due to the fact that the $\mathrm{N}$ element stimulates the vegetative growth of cotton plants by increasing amino acids and growth hormones formation which in turn acts positively for cell division and enlargement to produce new tissues. The positive effect of $\mathrm{N}$ on cotton has been reported by Saleh et al. (2004), El- Sayed and El- Menshawi (2005) and Toaima (2007).

\subsection{Photosynthtic pigments and total sugar estimations}

The data in Table (2) demonstrate that treating cotton plants with mineral-N combined with microbin or cerealin biofertilizers, significantly improved, chlorophyll a, chlorophyll b total carotenoids and total sugars. On the average $80 \%$ $\mathrm{N}+$ microbin or cerealin (T5 and T8) showed higher values than the other treatments for the previously traits in the two seasons. T8 treatment recorded the highest values for chlorophyll $\mathrm{b}$ and total carotenoids (i.e. $0.86,0.87,0.54$ and 0.56 for the two aforesaid traits in the first and second seasons, respectively. Moreover, it revealed the highest values for total sugars (34.93) and chlorophyll a (1.17) in the second season. While T5 treatment recorded the highest values of total sugars (32.90) and chlorophyll a (1.13) in the first season compared with the control. These pronounced increments may be due to the fact that organic matter content of the experimental soil $(1.47 \%)$ increased proliferation and activity of $\mathrm{N}$ fixing bacteria of biofertilizer, which led to more efficiency of cotton plant to accumulate $\mathrm{N}$ in leaves. Element of nitrogen is one of the essential chlorophyll components. It is as an important part of chlorophyll molecule. Similar trend was obtained by Hamissa et al. (2000).

In the meantime, $80 \% \mathrm{~N}, 60 \% \mathrm{~N}$ and $60 \%$ $\mathrm{N}+$ cerealin (T2, T3 and T9) treatments recorded beneficial effect and comparable values for leaf pigments and total soluble sugars traits. Also, the two treatments $\mathrm{T} 4$ and $\mathrm{T} 7$ recorded comparative values for the previous traits, but more than those values exerted of treatments $\mathrm{T} 2, \mathrm{~T} 3$ and $\mathrm{T} 9$.

\subsection{Yield and its components}

Average values of seed cotton and its 
Table (2): Mean values of photosynthetic pigments and total sugar estimates as affected by nitrogen fertilizer rates and biofertilizers in the two growing seasons.

\begin{tabular}{|c|c|c|c|c|c|c|c|c|}
\hline \multirow{2}{*}{ Treatments } & \multicolumn{2}{|c|}{$\begin{array}{l}\text { Total sugars } \\
\text { (mg/g, D. W.) }\end{array}$} & \multicolumn{2}{|c|}{$\begin{array}{c}\text { Chlorophyll a } \\
\text { (mg/g, F.W.) }\end{array}$} & \multicolumn{2}{|c|}{$\begin{array}{l}\text { Chlorophyll b } \\
\text { (mg/g, F.W.) }\end{array}$} & \multicolumn{2}{|c|}{$\begin{array}{c}\text { Total } \\
\text { carotenoids } \\
\text { (mg/g, F.W.) }\end{array}$} \\
\hline & $\begin{array}{c}1^{s t} \\
\text { season }\end{array}$ & $\begin{array}{c}2^{\text {nd }} \\
\text { season }\end{array}$ & $\begin{array}{c}1^{s t} \\
\text { season }\end{array}$ & $\begin{array}{c}2^{\text {nd }} \\
\text { season }\end{array}$ & $\begin{array}{c}1^{s t} \\
\text { season }\end{array}$ & $\begin{array}{c}2^{\text {nd }} \\
\text { season }\end{array}$ & $\begin{array}{c}1^{s t} \\
\text { season }\end{array}$ & $\begin{array}{c}2^{\text {nd }} \\
\text { season }\end{array}$ \\
\hline T1: $100 \% \mathrm{~N}$ (control) & 23.93 & 24.96 & 0.91 & 0.93 & 0.59 & 0.58 & 0.44 & 0.43 \\
\hline T2: $80 \% \mathrm{~N}$ & 25.83 & 26.33 & 0.96 & 0.97 & 0.66 & 0.65 & 0.41 & 0.39 \\
\hline T3: $60 \% \mathrm{~N}$ & 20.73 & 21.23 & 0.78 & 0.79 & 0.51 & 0.53 & 0.33 & 0.33 \\
\hline T4: $100 \% \mathrm{~N}+$ Microbin & 27.00 & 28.00 & 1.04 & 0.92 & 0.61 & 0.63 & 0.46 & 0.48 \\
\hline T5: 80\% N + Microbin & 32.90 & 34.30 & 1.13 & 1. & 0.83 & 0.86 & 0.53 & 0.52 \\
\hline T6: $60 \% \mathrm{~N}+\mathrm{M}$ & 21.47 & 22.20 & 0.73 & 0.83 & 0.55 & 0.52 & 0.33 & 0.35 \\
\hline T7: 100\% N + Cerealin & 25.00 & 25.67 & 1.02 & 0.95 & 0.67 & 0.69 & 0.48 & 0.49 \\
\hline T8: 80\% N + Cerealin & 31.56 & 34.93 & 1.02 & 1.17 & 0.86 & 0.87 & 0.54 & 0.56 \\
\hline T9: $60 \% \mathrm{~N}+$ Cerealin & 24.90 & 23.50 & 0.78 & 0.78 & 0.54 & 0.53 & 0.32 & 0.33 \\
\hline NEW LSD at 5 & 1.427 & 1.445 & 0.021 & 0.029 & 0.012 & 0.019 & 0.006 & 0.007 \\
\hline
\end{tabular}

Table (3):Mean values of yield and yield component traits as affected by nitrogen fertilizer rates and biofertilizers in the two growing seasons.

\begin{tabular}{|c|c|c|c|c|c|c|}
\hline \multirow[t]{2}{*}{ Treatments } & \multicolumn{2}{|c|}{$\begin{array}{l}\text { Seed cotton yield } \\
\text { (kentar/fed.)* }\end{array}$} & \multicolumn{2}{|c|}{ Number of bolls } & \multicolumn{2}{|c|}{ Boll weight (g) } \\
\hline & $\begin{array}{c}1^{\text {st }} \\
\text { Season }\end{array}$ & $\begin{array}{c}\mathbf{2}^{\text {nd }} \\
\text { season }\end{array}$ & $\begin{array}{c}\mathbf{1}^{s t} \\
\text { Season }\end{array}$ & $\begin{array}{c}2^{\text {nd }} \\
\text { season }\end{array}$ & $\begin{array}{c}\mathbf{1}^{\text {st }} \\
\text { season }\end{array}$ & $\begin{array}{c}2^{\text {nd }} \\
\text { season }\end{array}$ \\
\hline T1: $100 \%$ N (control) & 7.16 & 6.49 & 16.36 & 15.76 & 2.26 & 2.22 \\
\hline T2: $80 \% \mathrm{~N}$ & 6.10 & 5.56 & 13.56 & 12.63 & 2.33 & 2.10 \\
\hline T3: $60 \% \mathrm{~N}$ & 5.48 & 5.10 & 13.06 & 13.26 & 2.17 & 2.08 \\
\hline T4: $100 \%$ N + Microbin & 6.90 & 5.61 & 16.56 & 16.40 & 2.47 & 1.85 \\
\hline T5: $80 \%$ N + Microbin & 7.48 & 7.53 & 17.93 & 15.30 & 2.45 & 2.42 \\
\hline T6: $60 \%$ N + Microbin & 5.96 & 6.08 & 13.33 & 14.00 & 2.31 & 2.09 \\
\hline T7: $100 \% \mathrm{~N}+$ Cerealin & 7.08 & 6.82 & 15.33 & 17.00 & 2.73 & 1.85 \\
\hline T8: $80 \%$ N + Cerealin & 7.81 & 7.75 & 17.76 & 16.66 & 2.56 & 2.28 \\
\hline T9: $60 \% \mathrm{~N}+$ Cerealin & 6.17 & 6.15 & 13.16 & 13.33 & 2.42 & 2.24 \\
\hline NEW LSD at $5 \%$ & 1.15 & 1.43 & 0.66 & 0.43 & 0.029 & 0.023 \\
\hline \multirow[b]{2}{*}{ Treatments } & \multicolumn{2}{|c|}{ Lint percentage $(\%)$} & \multicolumn{2}{|c|}{ Seed index (g) } & \multicolumn{2}{|c|}{ Lint index (g) } \\
\hline & $\begin{array}{c}1^{s t} \\
\text { Season }\end{array}$ & $\begin{array}{c}2^{n d} \\
\text { Season }\end{array}$ & $\begin{array}{c}\mathbf{1}^{s t} \\
\text { Season }\end{array}$ & $\begin{array}{c}2^{\text {nd }} \\
\text { Season }\end{array}$ & $\begin{array}{c}\mathbf{1}^{s t} \\
\text { Season }\end{array}$ & $\begin{array}{c}2^{\text {nd }} \\
\text { season }\end{array}$ \\
\hline T1: $100 \% \mathrm{~N}$ (control) & 35.90 & 33.96 & 9.37 & 9.58 & 5.25 & 4.93 \\
\hline T2: $80 \% \mathrm{~N}$ & 33.56 & 32.33 & 9.50 & 9.45 & 4.80 & 4.51 \\
\hline T3: $60 \% \mathrm{~N}$ & 34.03 & 30.93 & 6.67 & 9.20 & 4.65 & 4.12 \\
\hline T4: $100 \%$ N + Microbin & 36.40 & 35.90 & 9.30 & 9.68 & 5.32 & 5.42 \\
\hline T5: $80 \%$ N + Microbin & 38.93 & 36.53 & 10.38 & 10.16 & 6.62 & 5.85 \\
\hline T6: $60 \%$ N + Microbin & 32.13 & 31.93 & 9.17 & 9.10 & 4.34 & 4.27 \\
\hline T7: $100 \%$ N + Cerealin & 36.70 & 33.33 & 9.35 & 9.90 & 4.42 & 4.95 \\
\hline T8: $80 \%$ N + Cerealin & 40.40 & 37.53 & 10.45 & 10.46 & 7.09 & 6.32 \\
\hline T9: $60 \% \mathrm{~N}+$ Cerealin & 32.73 & 31.50 & 9.073 & 9.30 & 3.75 & 4.27 \\
\hline NEW LSD at $5 \%$ & 0.335 & 0.740 & 0.019 & 0.038 & 0.017 & 0.021 \\
\hline
\end{tabular}

components are given in Table (3). It is obvious that the treatments caused highly significant differences regarding, seed cotton yield, the number of bolls, boll weight, lint (\%), seed index and lint index. These results showed that microbin or cerealin combined with mineral $80 \%$ of $\mathrm{N}$ fertilizer significantly increased seed yield and its contributors compared with mineral in both seasons except the control treatment. The data showed that the best results were obtained with 
the two treatments of $\mathrm{T} 5$ and $\mathrm{T} 8$ followed by $\mathrm{T} 4$, $\mathrm{T} 6, \mathrm{~T} 7$ and $\mathrm{T} 9$ treatments indicating the beneficial effect of the biofertilizer on these traits. These results also indicated that the importance of the number of bolls and boll weight traits resulted in the positive effect on seed cotton yield. The results showed that the highest values for seed cotton yield (7.53 and 7.75 kentar/fed.) for T5 and T8 treatments occurred in the second seasons, respectively. The corresponding obtained values were 7.48 and 7.81 for the same traits in the first season.

Increasing seed cotton yield and its components after biofertilizers application was also explained by Al- Mohamed et al.(2009) and confirmed by Chowdhury and Mukherjee (2008).

These results are in accordance with those obtained by Sundaravardarajan et al. (2006) who found that the increased number of bolls, boll weight and seed cotton yield traits may be due to the desirable effect of biofertilizers. In this respect, seed cotton yield may sometimes be limited by photosynthesis. The promoting effect of biofertilization on leaf pigments concentration might be attributed to the enhancing effect of biofertilizer on the nutritional status of cotton plants.

In conclusion, judging from seed cotton yield, the results of the present study clearly indicated that, using of bio-fertilizers reduced the environmental pollution, caused from the chemical ones and to improve the growth and cotton yield traits.

These fertilizers promote the different metabolic processes which increased syntheses of chlorophyll and absorption of essential nutrients, and could be increase seed cotton yield trait. Based on the present results it could be concluded that the application of $80 \% \mathrm{~N}+$ cerealin or microbin were favorable treatments for producing relatively high yield through improved growth traits, and proved to be a best way for saving $20 \%$ of $\mathrm{N}$ fertilizer and avoiding its undesirable effects.

\section{REFERENCES}

Allen O.N. (1971). Experiments in Soil Bacteriology. Burgess Publishing Minneapolis, Minnesota, USA.

Al- Mohamed H. K, Fayed T.B., Mostafa M.T., Sleim Sh. M. and Saudy H. S. (2009). Preliminary studies on the effect of foliar application of methanol and pink pigmented facultative methelotrophic bacteria on cotton plant. Arab Univ. J. Agric. Sci., Ain Shams Univ., Cairo, 17 (1): 57-63.
A.O.A.C. (1995). Official Methods of Analysis of Association Official Agricultural Chemist. Franklin Station., Washington D.C.

Arnon D.I. (1949). Copper enzymes in isolated chloroplasts. Polyphenol-oxidase in Beta vulgaris L. Plant Physiol., 24: 1-5.

Chowdhury A. and Mukherjee P (2008). Biofertilizers. News Letter, ENVIS Centre on Environmental Biotechnology., 9:1-8.

El-Sayed E. A. and El- Menshawi M. (2005). Response of the promising hybrid cotton Giza $89 \times 86$ to hill spacing and nitrogen fertilizer level. J. Agric. Res. Tanta Univ., 31 (3): 436-456.

Gomeze K. A. and Gomeze A. A. (1984). Statistical Procedures for Agricultural Research. $2^{\text {nd }}$ ed. John Wiley and Sons. Inc., New York, USA.

Hamed F. S. (2006). Response of cotton cultivar Giza 90 to population density and nitrogen levels. Assuit J. of Agric. Sci., 37 (3): 1743185.

Hamissa, A. M., Ziadah K. A. and El-Masry M. F. (2000). Response of cotton to biofertilizer and nitrogen fertilization. Minufiya. J . Agric. Res., 25 (2): 371-388.

Ibrahim E.M ., Bassal S.A.A. and Bader M.M.A. (2004). Effect of tillage systems, biofertilization and spraying urea on wheat productivity . Zagazig Agric. Res., 31 (2): 491-507.

Kannaiyan S. (2002). Biotechnology of Biofertilizers Alpha sci. Inter. Ltd. P.O Box 4067 Pang Boorne R. 68 M. K. pp 1-275.

Klute A. (1986). Methods of soil analysis- part 1, physical and mineralogical methods. $2^{\text {nd }}$ edition. American society of Agron. Madison, Wisconsin, U.S.A.

Megawer A. Ekram. and Mahfouz S. A. (2010). Response of canola (Brassica napus L.) to biofertilizers under Egyptian condition in newly reclaimed soil. Inter. J. of Agric. Sci., 2 (1): 12-17.

Neeru N., Kumar V., Baljeet S., Bhatia R., Bishnoi L.K. and Lakshminarayana K. (2005b). Impact of biofertilizers on grain yield in spring wheat under varying fertility conditions and wheat-cotton rotation. Archives of Agronomy and Soil Science. 51 (1): 79-89.

Neeru N., Saharan B.S., Kumar V., Bhatia R., Bishnoi L.K., Lather B.P.S and Lakshminarayana K. (2005a). Impact of the use of biofertilizers on cotton ( Gossypium hirsutum) crop under irrigated agro- 
ecosystem. Archives of Agronomy and Soil Science. 51 (1): 66-71.

Page A. I., Miller R. H. and Keeney D. R. (1982). Methods of soil Analysis-part 2. Chemical and microbiological properties. 2nd Edition. American Society of Agronomy Madison, Wisconsin U.S.A.

Rokhzadi A., Asgharzadeh A., Darvish F., NourMohammadi G. and Majidi E. (2008). Influence of plant growth promoting rhizobacteria on dry matter accumulation and yield of chickpea (Cicer arietinum L.) under field condition. American Eurasian J. Agric. \& Environ. Sci., 3(2): 253-257.

Saleh M. E., Ghanem S. A. I., Zeiton O. A. A. and Reshed G. I. M. (2004). Effect of planting date, density and nitrogen fertilization on shedding, earliness, yield and fiber quality of Egyptian cotton. Zagazig J. Agric. Res. 31(69): 2597-2620.

Singh P. K. and Bisoyi R. N. (1995). Biofertilizers for restoration of soil fertility . Restoration of Degraded land : Concepts and Strategies $.25-47 ; 135$ ref.

Sobh M. M., Genaidy S. and Hegazy M. (2000). Comparative studies on mineral and biofertilzation for some main field crops in Northern Delta soils, Zagazig J. Agric. Res., 27 (1): 171-179.
Sundaravardarajan, K. R., Jahanmohan K. R. and Swaminathan L.P. (2006). Constraints in adoption of bio-input usage in cotton cultivation. Agric. Econ. Res. Rev., 19: 155-164.

Toaima S. E. A. (2007). Effect of crop rotation and nitrogen fertilization on yield, yield components and associated weeds in cotton. Arab Univ. J. Agric. Sci., Ain Shams Univ., Cairo, 15 (2): 349-359.

Welburm A.R. and H. Lichtenthaler (1984). Formulae and program to determine total carotenoids and chlorophyll $\mathrm{a}$ and $\mathrm{b}$ of leaf extracts different solvents. In Advances phostosynthesis research (Sybesma C. Ed.) 11:pp. 9-12. Mortinus Njihoff Dr W Junk publishers, the Hague.

Wu S.C, Cao Z.H., Li Z.G., Cheung K. C. and Wong M. H (2005). Effects of biofertilizer containing $\mathrm{N}$-fixer, $\mathrm{P}$ and $\mathrm{K}$ solubilizers and AM fungi on maize growth in a greenhouse trial. Geoderma, 125 : 155-166. Available online at Sciencedirect. Com.

Zeidan E.M., El-Khawaga A.A., Basha H.A. and Abd El- Hammeed I.M. (2005). Improvement of wheat productivity in newly reclaimed soil in Egypt. Annals Universitatis Mariae Curie -Sklodowska. 60: 113-121.

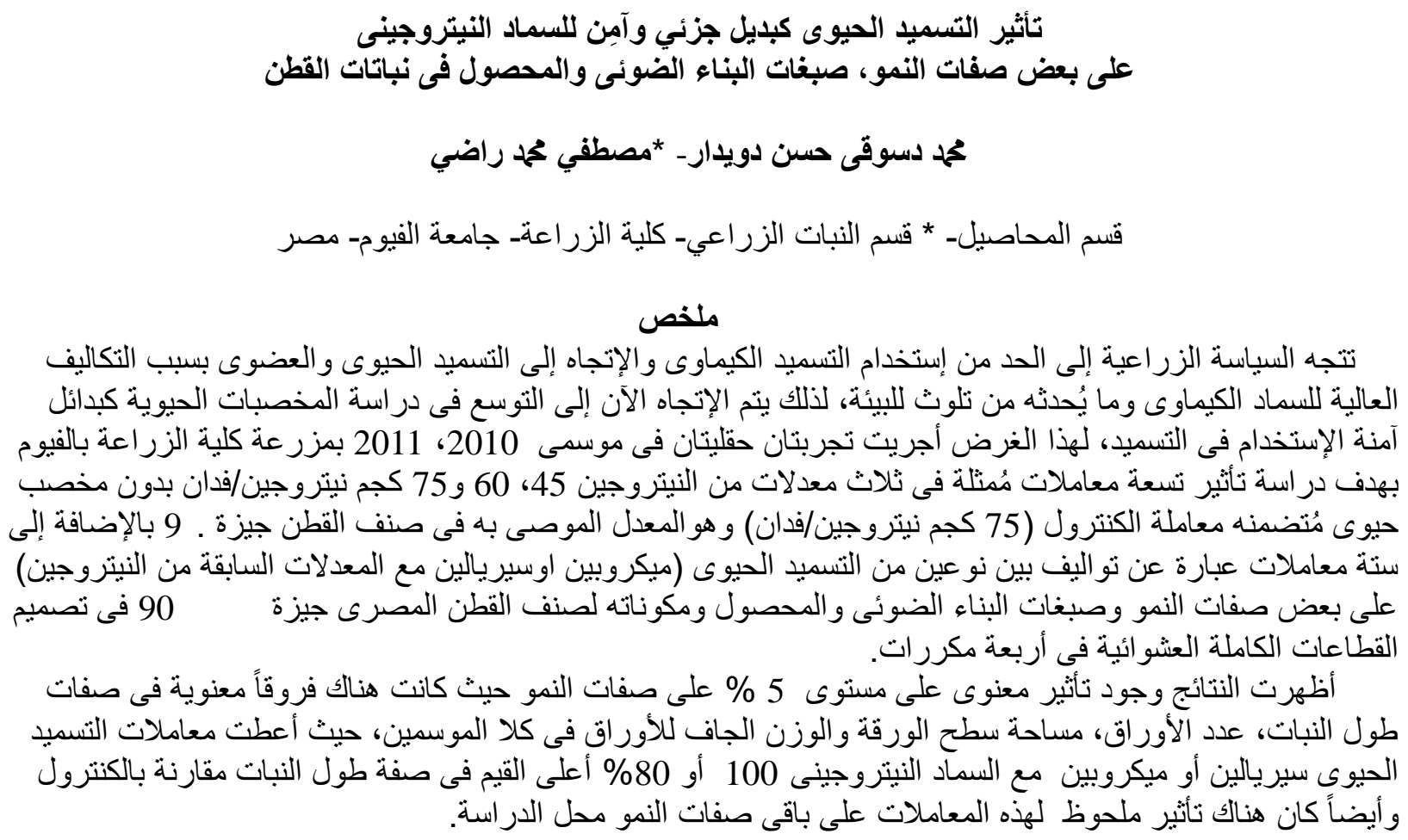


أوضحت الدر اسة أن كلوروفيل أ، كلوروفيل ب، الكاروتتويدات الكلية والسكريات الكلية قد نأثرت جميعها معنوياً و إيجابياً

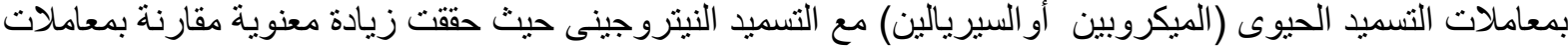

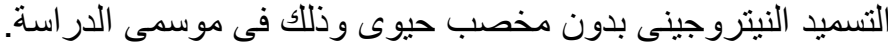

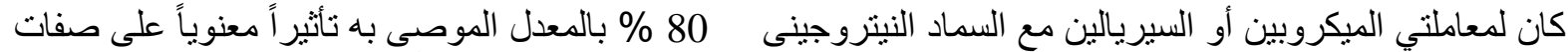

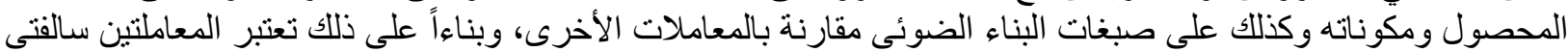

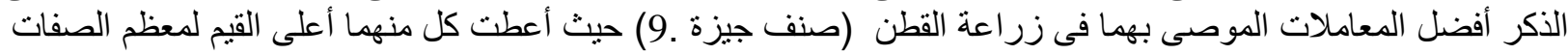

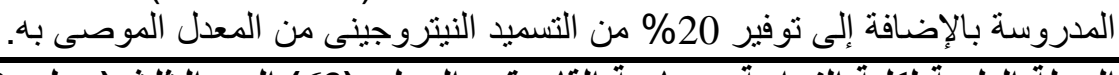

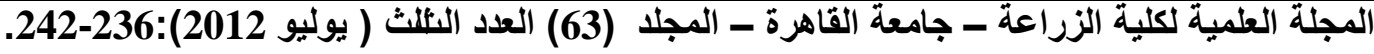

